\title{
Organizacja i finansowanie szkół kształcących zawodowo przez powiaty
}

DOI: 10.47050/65591814.244-271

Agnieszka Kopańska

Organizacja i finansowanie szkół kształcących zawodowo to obowiązek samorządów powiatowych w Polsce. Jednak faktyczne możliwości jego realizacji wiążą się z czynnikami, na które powiaty nie mają wpływu. Zmiany demograficzne powodują, że młodych ludzi jest coraz mniej, a to sprawia, że koszt nauczania jednego ucznia rośnie. Na liczbę uczniów w szkołach kształcących zawodowo przekładają się również decyzje edukacyjne młodzieży. Coraz mniej młodych ludzi podejmuje naukę w szkołach zawodowych, a dodatkowo coraz większa ich liczba wybiera naukę w największych miastach. Ostatecznie najwięcej uczniów ubywa w powiatach peryferyjnych. Jednocześnie właśnie te ośrodki mają najmniejsze możliwości finansowe. Powoduje to, że mimo mniejszej liczby młodzieży w szkołach, wydają one na ucznia mniej niż większe i bogatsze ośrodki. Ta sytuacja może prowadzić do znacznych nierówności w jakości oferty edukacyjnej i wymaga szczególnej troski podczas kolejnych reform systemu edukacji zawodowej w Polsce.

\section{Słowa kluczowe:}

edukacja zawodowa

finanse lokalne

koszty kształcenia

decentralizacja 


\section{Financing and organization of vocational schools by poviats}

DOI: 10.47050/65591814.244-271

Agnieszka Kopańska

Organization and financing of vocational schools is the responsibility of poviats in Poland. However, the actual performance of this obligation is related to factors for which poviats do not have an impact. First, demographic changes mean that there are less young people which makes the cost of teaching per one student grow. The number of students in vocational schools is also influenced by the educational decisions of the students themselves. A smaller group of young people enrollees in vocational schools and an increasing number of young people educates in major cities. Peripheral poviats lose students the most. At the same time, these peripheral poviats have the smallest financial possibilities. The result is that despite the smaller number of students they spend less per student than larger and richer cities. This situation may lead to important differences in the quality of the educational offer. It requires special attention during subsequent reforms of the vocational education system in Poland.

Keywords:

vocational education

local finance

cost of education

decentralization 
W niniejszym rozdziale przedstawiono analizę różnic w organizacji i finansowaniu szkolnictwa zawodowego w powiatach w Polsce. Wskazano najważniejsze czynniki, które na różnice te wpływają. Analiza ta koncentruje się na sytuacji w 2016 r. i na szkołach dla młodzieży. Państwo zgodnie z konstytucyjnym zobowiązaniem musi zapewnić młodym ludziom możliwość realizacji obowiązkowej edukacji do 18. roku życia. Najważniejszą metodą realizacji tego obowiązku jest organizacja szkół dla młodzieży. Zrozumienie problemów i wyzwań, jakie się z tym wiążą, jest ważne dla kształtowania systemu edukacji, w tym kształcenia zawodowego w Polsce. W miarę dostępności i porównywalności danych w niniejszym opracowaniu pokazano tendencje w szkolnictwie zawodowym z ostatnich kilkunastu lat. Rok 2016 to ostatni rok funkcjonowania systemu szkolnictwa $w$ dotychczasowym kształcie. Zatem prezentacja dla 2016 r. stanowi obraz wyjściowy dla nowych reform wprowadzanych od roku szkolnego 2017/2018. Pozwoli to również wskazać najważniejsze problemy dotychczasowej organizacji i sposobu finansowania szkolnictwa zawodowego, które powinny być uwzględnione przez instytucje odpowiedzialne za reformę szkolnictwa.

\section{Rola powiatów w systemie szkolnictwa zawodowego po 1999 r.}

System kształcenia zawodowego młodzieży w kształcie z 2016 r. został stworzony w 1999 r. przez dwie reformy - edukacji i administracji. Pierwsza wprowadziła nową organizację systemu kształcenia, druga nowe jednostki w strukturze samorządu, które stały się odpowiedzialne za szkoły dla młodzieży.

Przypomnienie, po raz kolejny w tym opracowaniu, reformy edukacji z 1999 r. ma swoje uzasadnienie w powiązaniu jej organizacyjnie i finansowo $z$ reformą administracyjną. W zakresie zmian w edukacji, po pierwsze, wydłużono okres edukacji obowiązkowej i jednolitej dla wszystkich z ośmiu do dziewięciu lat, wprowadzając po sześcioletniej szkole podstawowej (skrócono w niej naukę z ośmiu do sześciu lat) trzyletnie gimnazjum. Po drugie, zgodnie z pierwotnymi założeniami reformy wśród szkół ponadgimnazjalnych miały dominować licea ogólnokształcące i profilowane (zastępowały one dotychczasowe licea zawodowe i technika), w których miało kształcić się $80 \%$ młodzieży. Szkoły zawodowe, powołane w miejsce zasadniczych szkół zawodowych, miały oferować dwuletnią naukę zawodu. Zgodnie z tymi założeniami wy- 
kształcenie zawodowe można było uzyskać w liceum profilowanym, szkole zawodowej, a także w szkole policealnej o profilu zawodowym. Jednak w praktyce nie udało się wprowadzić wszystkich planowanych zmian w organizacji szkół ponadgimnazjalnych. Stworzono wprawdzie licea profilowane, ale w systemie edukacyjnym przywrócono technika i większość szkół, które oferowały kształcenie zawodowe lub ogólnozawodowe przed wprowadzeniem reformy. W rezultacie tych zmian (tworzenia i przywracania poprzednich rozwiązań) od 1 września 2004 r. w systemie edukacji funkcjonowało osiem typów szkół ponadgimnazjalnych, w tym sześć oferujących kształcenie zawodowe lub ogólnozawodowe. Mimo że nadal dominowały szkoły oferujące kształcenie zawodowe, ilościowe założenie reformy - o ograniczeniu liczby młodzieży w zasadniczych szkołach zawodowych - zostało zrealizowane. Gdy w połowie lat 90 . do zasadniczych szkół zawodowych uczęszczała ok. 1/3 młodzieży, to po reformach wprowadzających gimnazjum i nowe typy szkół zawodowych tylko 15\% uczniów decydowało się na wybór tego typu kształcenia (Oświata i wychowanie... 2017, s. 74). Tego trendu nie zmieniły reformy wdrażane od $2011 \mathrm{r}$. pod hasłem "szkoła zawodowa szkołą pozytywnego wyboru".

Reforma administracji z 1999 r. wprowadziła dwa nowe szczeble samorządu w Polsce - oprócz gmin powstały powiaty i województwa. Samorządowi powiatowemu powierzono zadania z zakresu organizacji i finansowania szkolnictwa ponadgimnazjalnego i policealnego. Do realizacji tego zadania skierowano do samorządów część oświatową subwencji ogólnej, jednak nie ma ona na celu sfinansowania zadań oświatowych, a jedynie ich dofinansowanie. Zadania z zakresu oświaty są bowiem zadaniami własnymi samorządów, zatem na ich sfinansowanie przeznaczone są również dochody własne samorządu oraz inne części subwencji ogólnej. Należy podkreślić, że w praktyce funkcjonują dwa typy samorządu powiatowego - powiaty ziemskie (314 jednostek) oraz grodzkie (661 jednostek). Te drugie nazywane są również miastami na prawach powiatu, gdyż są to największe miasta, które są jednocześnie gminami i powiatami. Oznacza to, że zarówno zakres zadań, jak i dochody tych podmiotów są znacznie większe niż powiatów ziemskich. Co więcej, w 1999 r., kiedy powstały powiaty, miasta miały już 
doświadczenie w zarządzaniu sprawami publicznymi, w tym oświatą (szkołami podstawowymi, a niektóre również ponadpodstawowymi2), natomiast powiaty ziemskie to były nowe podmioty.

Prowadzenie i finansowanie szkolnictwa ponadgimnazjalnego stało się zatem od $1999 \mathrm{r}$. zadaniem własnym samorządu powiatowego. Oprócz tego powiaty pod koniec 2016 r. realizowały zadania oświatowe w szkołach podstawowych specjalnych i gimnazjach specjalnych, szkołach ponadgimnazjalnych z oddziałami integracyjnymi, szkołach sportowych i mistrzostwa sportowego oraz placówkach oświatowo-wychowawczych, [...], placówkach artystycznych; poradniach psychologiczno-pedagogicznych; młodzieżowych ośrodkach wychowawczych [...], placówkach zapewniających opiekę i wychowanie uczniom w okresie pobierania nauki poza miejscem stałego zamieszkania, z wyjątkiem szkół i placówek o znaczeniu regionalnym i ponadregionalnym ${ }^{3}$. W odniesieniu do szkolnictwa zawodowego należy podkreślić odpowiedzialność powiatów nie tylko za szkoły, ale również za placówki kształcenia ustawicznego, placówki kształcenia praktycznego oraz ośrodki dokształcania i doskonalenia zawodowego, umożliwiające uzyskanie i uzupełnienie wiedzy, umiejętności i kwalifikacji zawodowych4. Dodatkowo miasta na prawach powiatu wykonywały zadania przypisane do samorządu gminnego, realizowane $w$ przedszkolach oraz w innych formach wychowania przedszkolnego [...], a także w szkołach podstawowych oraz gimnazjach5. Oprócz szkół publicznych prowadzonych przez samorządy działają na ich terenie również szkoły niepubliczne mające uprawnienia szkół publicznych. Jednak samorząd nie ma wpływu na ich powstawanie (kuratorium wydaje opinię o spełnieniu właściwych wymagań przez taką szkołę). Jest natomiast zobowiązany kierować do w ramach którego samorządy przejęły niektóre zadania od administracji rządowej, w tym szkoły ponadpodstawowe. par. 2. Ten i kolejne cytaty ustaw dotyczą stanu prawnego na koniec 2016 r. Jest to ważny element kształcenia zawodowego, jednak jego szczegółowa analiza jest niemożliwa ze względu na to, że w statystyce publicznej nie ma danych o liczbie tych placówek i liczbie osób z nich korzystających. 
tych szkół dotacje. Jak zostanie pokazane dalej, jest to jednak bardzo niewielka część wydatków samorządów na szkoły. Stąd kwestie organizacji i finansowania szkół przez samorządy dotyczą przede wszystkim szkół publicznych.

Na wykresie 1 pokazano strukturę wydatków bieżących samorządów powiatowych na oświatę w 2016 r. Przedstawione dane dotyczą wydatków notowanych w dziale 801 (Oświata i wychowanie) klasyfikacji budżetowej w rozbiciu na poszczególne jej rozdziały. Jak widać, największa część wydatków powiatów dotyczy bezpośrednio placówek szkolnych. W powiatach ziemskich w strukturze wydatków na oświatę zdecydowanie przeważają wydatki na szkoły zawodowe i licea ogólnokształcące. Decydowały one ogółem o $71 \%$ wydatków powiatów ziemskich na oświatę. W przypadku miast na prawach powiatu wydatki na te szkoły stanowiły w 2016 r. 24\% ogółu ich wydatków na oświatę. Największa część wydatków była w największych miastach przeznaczana na szkoły podstawowe, przedszkola i gimnazja.

Wykres 1. Struktura wydatków bieżących powiatów na oświatę (dział 801) w 2016 r. (w \%)

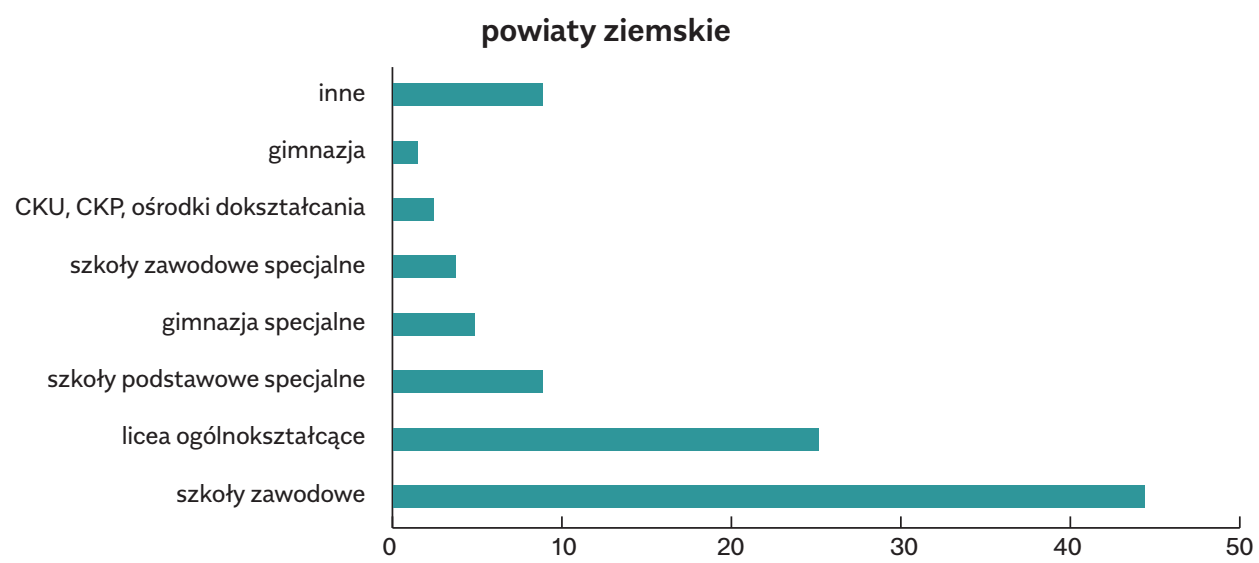




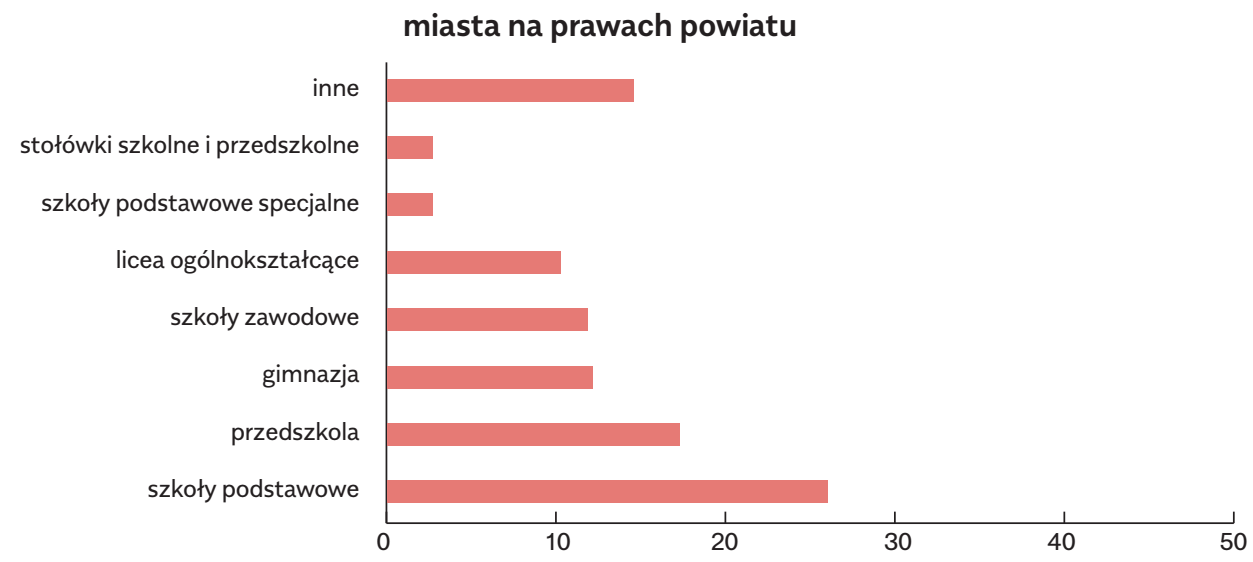

Źródło: opracowanie własne na podstawie danych z sprawozdania budżetowego RB28.

Rozdział klasyfikacji budżetowej - "szkoły zawodowe" obejmował w 2016 r. wydatki na zasadnicze szkoły zawodowe i technika. W obu przypadkach są to tylko szkoły dla młodzieży. Nie działały już w tym roku technika uzupełniające. Oprócz tego w rozdziale "szkoły zawodowe" zapisywano w 2016 r. wydatki na szkoły policealne dla młodzieży i dorosłych. To połączenie tak wielu różnych szkół w jeden rozdział klasyfikacji budżetowej utrudnia precyzyjną ocenę wydatków na poszczególne typy szkół. Rozwiązanie to było od lat krytykowane, jednak rozdzielenie typów szkół ujętych w klasyfikacji budżetowej w tej kategorii nastąpiło dopiero w 2018 r.

Poza powiatami również inne jednostki samorządu terytorialnego, a także ministerstwa mogą zakładać i prowadzić szkoły. $Z$ kolei w przypadku szkół niepublicznych o uprawnieniach publicznych są to też osoby prawne i fizyczne. Jak pokazuje wykres 2, większość techników (82\%) i zasadniczych szkół zawodowych dla młodzieży (76\%) jest prowadzona przez samorządy powiatowe. Jeśli przyjrzymy się strukturze uczniów w tych szkołach, to w sensie ilościowym przewaga samorządów powiatowych jest jeszcze większa. Odpowiednio, 85\% uczniów zasadniczych szkół zawodowych i 92\% techników to uczniowie szkół, których organem prowadzącym jest powiat. 
Wykres 2. Struktura szkół i uczniów w szkołach dla młodzieży

kształcących zawodowo według gestora w 2016 r. (w \%)

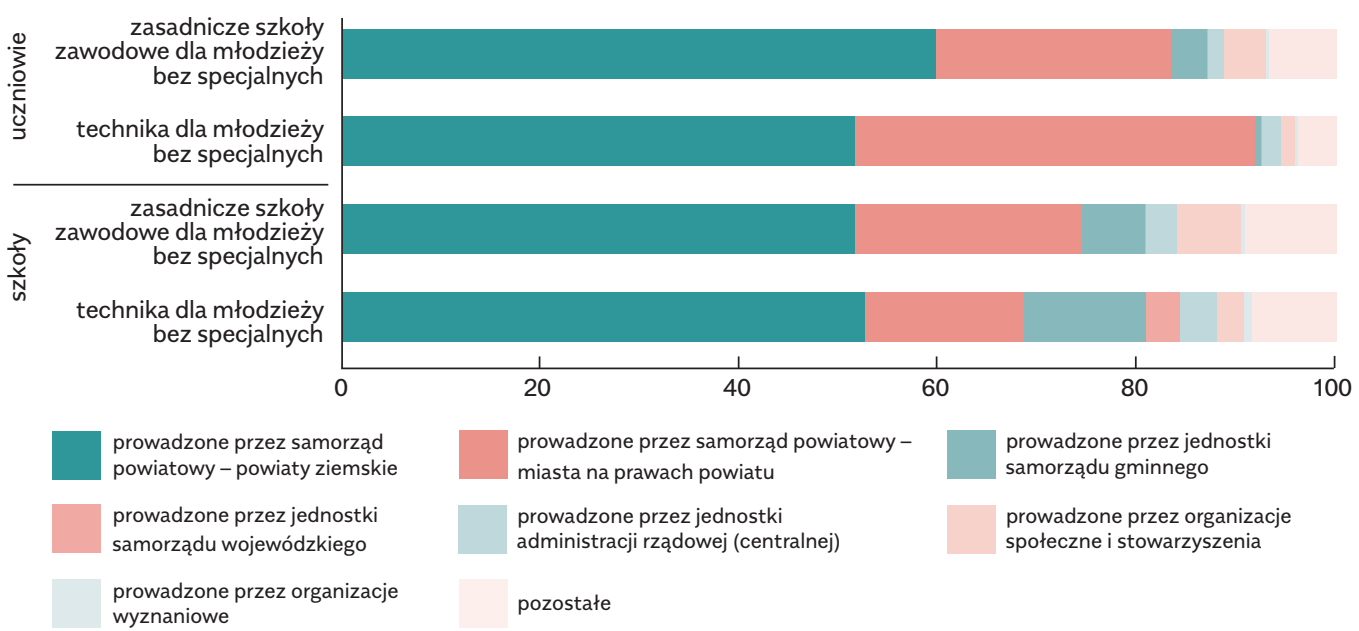

Źródło: opracowanie własne na podstawie danych BDL GUS.

Samorząd powiatowy organizuje i finansuje szkoły publiczne prowadzone przez siebie. W przypadku, gdy takie szkoły są prowadzone przez inne samorządy lub ministerstwa, podmioty te stają się odpowiedzialne za ich organizację i finansowanie. Jak pokazuje wykres 3, powiaty wydają na szkoły zawodowe najwięcej spośród wszystkich samorządów. 
Wykres 3. Udział samorządów poszczególnych szczebli

w wydatkach bieżących na szkoły zawodowe (w \%)

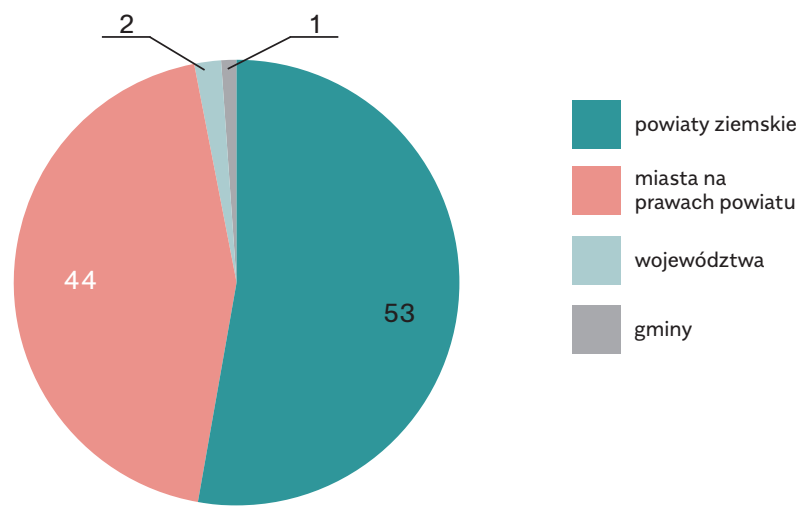

Źródło: opracowanie własne na podstawie danych ze sprawozdania budżetowego RB28.

Jeśli szkoła jest prowadzona przez podmiot prywatny lub społeczny, otrzymuje od samorządu powiatowego dotację odpowiadającą bieżącym wydatkom na ucznia szkoły publicznej danego typu. Dzięki temu, że dotację tę jesteśmy w stanie wydzielić z wydatków na szkoły (pozwala na to klasyfikacja budżetowa), możemy szczegółowo przeanalizować także wydatki na szkoły prowadzone wyłącznie przez powiaty. Jest to ważne również dla zniwelowania problemów w analizie, jakie stwarza połączenie w jeden rozdział klasyfikacji budżetowej techników i zasadniczych szkół zawodowych oraz szkół policealnych. Znaczna większość szkół policealnych (ok. $85 \%$ ) jest prowadzona przez inne niż powiat podmioty, a do powiatowych szkół policealnych uczęszcza tylko ok. $6 \%$ uczniów. Dotacje dla innych podmiotów stanowią $6 \%$ wydatków bieżących na szkoły zawodowe w powiatach ziemskich i $16 \%$ wydatków powiatów grodzkich. Pozostałe wydatki zapisywane w klasyfikacji budżetowej na szkoły zawodowe stanowią w większości wydatki na technika i zasadnicze szkoły zawodowe prowadzone przez powiaty.

\section{Wydatki powiatów na szkoły ksztalcące} zawodowo i ich zróżnicowanie

Na wykresie 4 przedstawiono poziom wydatków bieżących ogółem i udział w wydatkach bieżących ogółem wydatków bieżących samorządów powiatowych na szkoły zawodowe (technika i zasadnicze szko- 
ły zawodowe) prowadzone przez te podmioty w latach 2004-2016. Jak widać, mamy do czynienia z nieznacznym wzrostem wydatków powiatów (w okresie 2004-2016 o ok. 14\% w powiatach ziemskich i $24 \%$ w miastach na prawach powiatu, przy czym w okresie tym w 84 powiatach ziemskich i w 6 miastach na prawach powiatu wydatki na szkoły kształcące zawodowo spadły).

Jednocześnie wzrost ten jest mniejszy niż wzrost innych wydatków bieżących samorządów w tym okresie i, jak pokazuje wykres 4, w latach 2004-2016 udział wydatków na szkoły kształcące zawodowo w całości bieżących wydatków powiatów spadł. W 2004 r. wynosił on, odpowiednio, $19 \%$ w powiatach ziemskich i $5 \%$ w miastach na prawach powiatu, a w 2016 r. było to, odpowiednio, 15\% i 3\%.

Wykres 4. Wysokość wydatków bieżących na szkoły kształcące zawodowo prowadzone przez powiaty i udział tych wydatków w całości wydatków bieżących powiatów w latach 2004-2016 (wartości realne z 2016 r.)

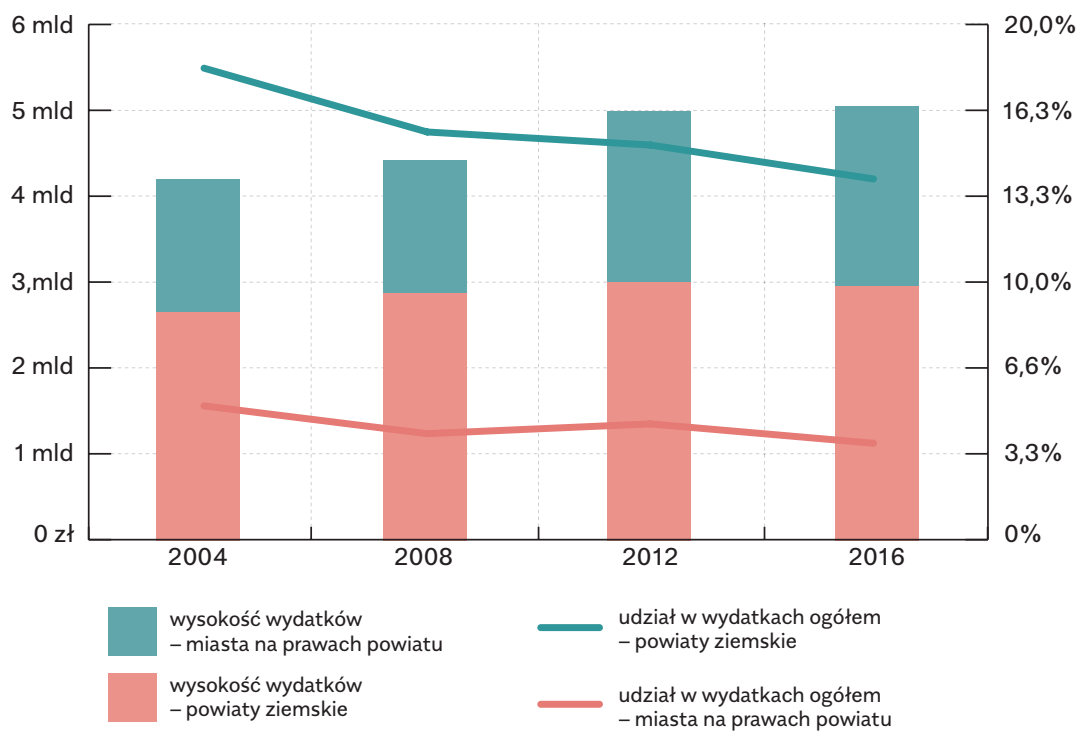

Źródło: opracowanie własne na podstawie danych z sprawozdań budżetowych RB28.

Jak pokazuje tabela na kolejnej stronie, wydatki te znacznie różnią się między powiatami. 
Tabela 1. Zróżnicowanie wydatków na szkoły powiatowe

dla młodzieży kształcące zawodowo w 2016 r. (w PLN)

\begin{tabular}{|c|c|c|c|c|}
\hline $\begin{array}{l}\text { jednostka samorządu } \\
\text { terytorialnego }\end{array}$ & średnia & mediana & minimum & maksimum \\
\hline & \multicolumn{4}{|c|}{ w przeliczeniu na ucznia } \\
\hline powiat ziemski & 8308,1 & 8078,5 & 1638,2 & 20201,0 \\
\hline $\begin{array}{l}\text { miasto } \\
\text { na prawach powiatu }\end{array}$ & 8876,4 & 8713,7 & 6021,1 & 13934,5 \\
\hline \multirow[t]{2}{*}{ razem $^{*}$} & 8408,1 & 8205,9 & 1638,2 & 20201,0 \\
\hline & \multicolumn{4}{|c|}{ udział w wydatkach bieżących ogółem (w \%) } \\
\hline powiat ziemski & 14,7 & 14,9 & 1,1 & 30,8 \\
\hline $\begin{array}{l}\text { miasto } \\
\text { na prawach powiatu }\end{array}$ & 4,6 & 4,4 & 1,4 & 9,3 \\
\hline ogółem* & 12,9 & 13,0 & 1,1 & 30,8 \\
\hline
\end{tabular}

* Ogólne statystyki dla powiatów i miast na prawach powiatu.

Źródło: opracowanie własne na podstawie danych ze sprawozdań budżetowych

RB28 i danych BDL GUS.

W przeliczeniu na ucznia wydatki w szkołach kształcących zawodowo prowadzonych przez powiaty wynosiły w 2016 r. od niecałych 2 tys. zł do ponad 20 tys. zł. Zarówno mediana, jak i przeciętna wydatków są niższe w powiatach ziemskich niż w powiatach grodzkich (tabela 1). W odniesieniu do wydatków bieżących ogółem wydatki na szkoły powiatowe kształcące zawodowo dochodziły nawet do $30 \%$ w powiatach ziemskich i $9 \%$ w grodzkich, ale były też samorządy, gdzie stanowiły tylko ok. $1 \%$ wydatków.

Poziom wydatków samorządów na szkoły zależy od wielu czynników. Należy tu wyróżnić dwie grupy powiązanych ze sobą determinant (Kopańska, Sztanderska 2015, s. 123 i n.):

1. związane z cechami charakteryzującymi szkołę i jej uczniów, a wpływające przede wszystkim na koszty funkcjonowania szkoły (jak wielkość szkoły i typ prowadzonej edukacji);

2. charakteryzujące samorząd i jego mieszkańców, wpływające na możliwości i potrzeby wydatkowe samorządu (popyt), w tym dochody do dyspozycji, publiczne i prywatne. 


\section{Wielkość szkół kształcących zawodowo}

Wśród czynników kształtujących koszty funkcjonowania danej szkoły wymienia się przede wszystkim jej wielkość, mierzoną zarówno liczbą uczniów ogółem, jak i liczebnością poszczególnych oddziałów. Im więcej uczniów, tym wyższe wydatki ogółem. Jednak działa tu efekt skali, co oznacza, że każdy kolejny uczeń kosztuje mniej. Wynika to z przeznaczenia niektórych wydatków: część z nich jest wykorzystywana na uczniów nie jednostkowo, a w przeliczeniu na oddziały. Na przykład nauczyciel może pracować z podobną efektywnością z mniejszą i większą liczbą uczniów, a koszty stałe, np. związane z utrzymaniem budynku, są ponoszone niezależnie od tego, ilu uczniów uczy się w danej szkole. $Z$ tego powodu istotnym problemem w zarządzaniu szkołami jest utrzymanie szkoły odpowiedniej wielkości, takiej, która pozwala na minimalizację kosztów w przeliczeniu na ucznia.

Wykres 5. Liczba i struktura uczniów pierwszych klas szkół ponadgimnazjalnych dla młodzieży w latach 2012-2016* (w \%)

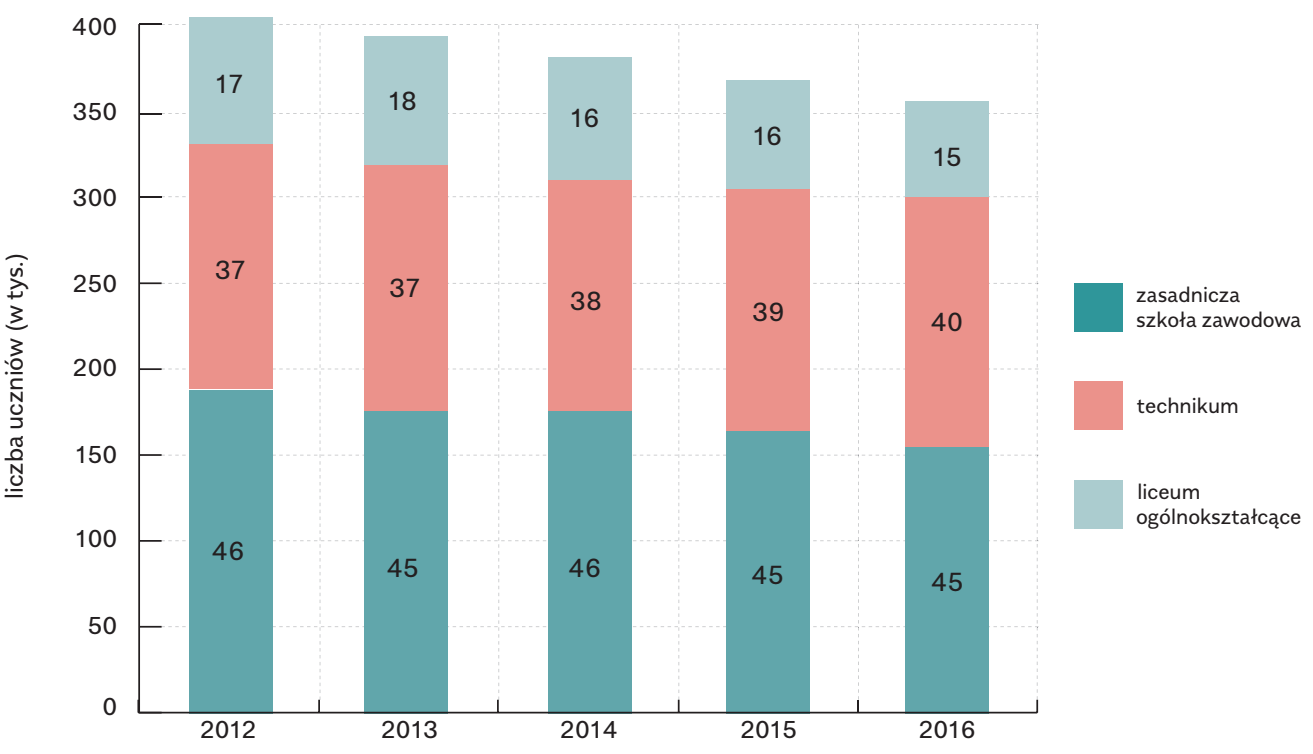

* Dla wcześniejszych lat nie ma danych GUS o uczniach pierwszych klas w szkołach ponadgimnazjalnych dla młodzieży, jednocześnie 2012 r. to pierwszy rok po reformach w kształceniu zawodowym.

Źródło: opracowanie własne na podstawie danych BDL GUS. 
Problem ubytku uczniów wynikający ze zmian demograficznych jest w ostatnich latach przedmiotem wielu analiz. Od 2000 r. liczba osób w wieku 16-19 lat (a więc młodzieży w wieku ponadgimnazjalnym) zmniejszyła się o 42\%, a jeśli przeanalizujemy tylko lata 2012-2016, jest to ubytek ok. $14 \%$. Zmiany te nie są jednolite na terenie całej Polski, np. w 66 powiatach w tym krótkim okresie liczba młodzieży zmniejszyła się o 1/5, a w dwóch powiatach w tym czasie nastąpił nieznaczny wzrost liczby młodych ludzi.

W przypadku analizy liczby uczniów w szkołach ponadgimnazjalnych ten ogólny trend trzeba połączyć z decyzjami samych uczniów (i ich rodziców) o tym, w jakiej szkole i w jakim miejscu podejmą edukację. Na wykresie 5 przedstawiono liczbę i strukturę uczniów w pierwszych klasach szkół ponadgimnazjalnych dla młodzieży.

Mapa 1. Współczynnik skolaryzacji dla młodzieży pierwszych klas szkół ponadgimnazjalnych, dane dla 2016 r.

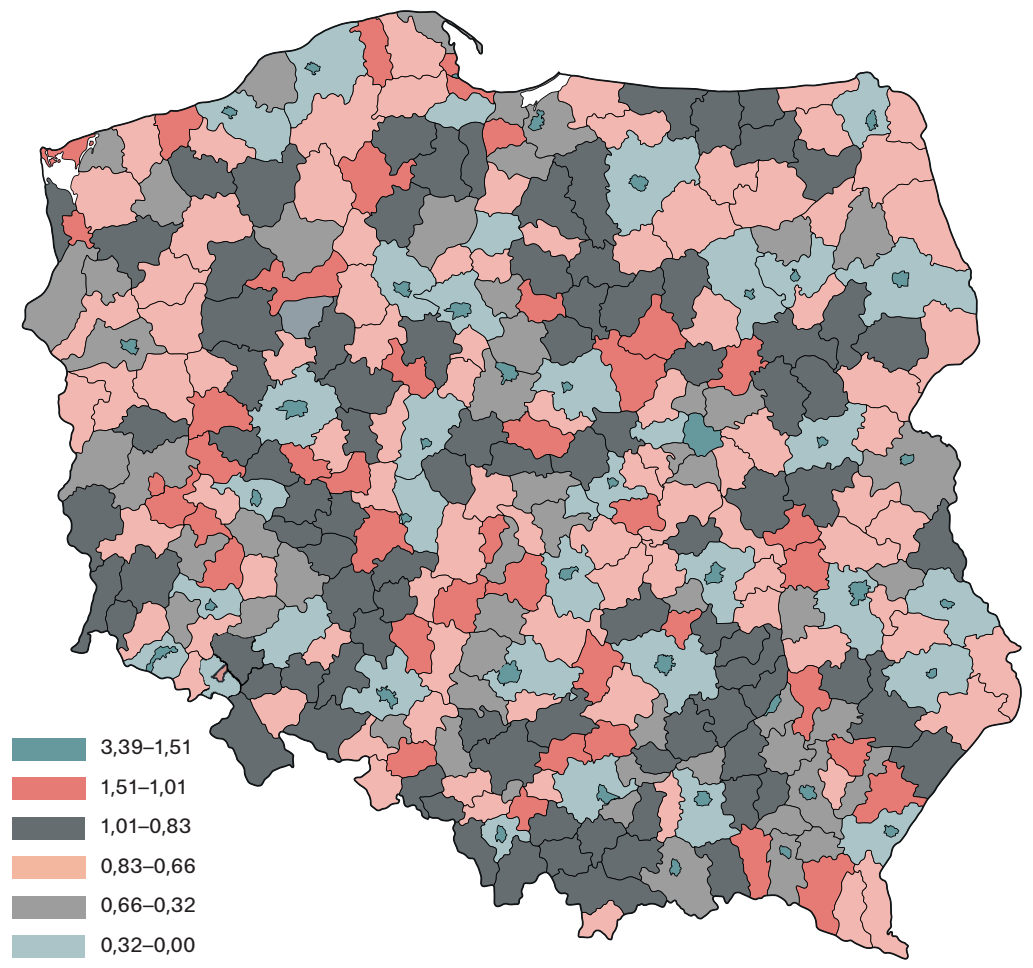

Źródło: obliczenia własne na podstawie danych BDL GUS. 
Jak pokazano na wykresie 5, malejąca liczba młodzieży jest faktem - co roku do szkół ponadgimnazjalnych trafia mniej uczniów. Szczegółowa analiza tych zmian w poszczególnych rejonach Polski pokazuje, że część powiatów straciła znacznie więcej uczniów niż inne i nie wynika to tylko z ogólnego trendu ubywania młodych mieszkańców, ale również z faktu, że decydują się oni na naukę poza powiatem. Na wykresie 2, gdzie pokazano strukturę uczniów w szkołach kształcących zawodowo prowadzonych przez różne podmioty, wyraźnie widać, że miasta na prawach powiatu mają duże znaczenie w tej strukturze. Mimo że grupa powiatów ziemskich jest prawie pięciokrotnie liczniejsza niż miast, to przewaga szkół prowadzonych przez te podmioty i uczniów nie jest tak znacząca. Dotyczy to szczególnie uczniów techników. W technikach prowadzonych przez powiaty ziemskie uczy się 53\% uczniów techników ogółem, a w tych kierowanych przez powiaty grodzkie $40 \%$. Warto dodać, że w przypadku liceów ogólnokształcących przewaga największych miast jest jeszcze większa (w szkołach prowadzonych przez miasta na prawach powiatu uczy się $47 \%$ uczniów liceów, a w tych zarządzanych przez powiaty ziemskie tylko $40 \%$ ). To właśnie do szkół w największych miastach decyduje się uczęszczać znacząca część młodzieży mieszkająca poza ich terenem. Znajduje to potwierdzenie na mapie 1. Pokazano na niej współczynnik skolaryzacji liczony dla uczniów klas pierwszych (a więc szesnastolatków). Liczba uczniów uczących się na terenie powiatu ${ }^{6}$ została podzielona przez liczbę szesnastolatków z tego powiatu. Współczynnik skolaryzacji równy jeden oznacza, że do szkół $w$ danym powiecie uczęszcza dokładnie taka sama liczba szesnastoletnich mieszkańców, jaka mieszka na terenie tego powiatu. Współczynnik mniejszy niż jeden oznacza, że część uczniów uczy się w innych powiatach, a współczynnik powyżej jedności mówi o tym, że w powiecie uczą się młodzi ludzie spoza jego terenu.

Należy zauważyć, że w przypadku prawie wszystkich miast na prawach powiatu ${ }^{7}$ tak wyliczony współczynnik skolaryzacji jest większy od jedności i również tam wartości tego współczynnika są największe

$6 \quad$ Uwzględniono tu uczniów szkół zlokalizowanych na terenie danego powiatu, prowadzonych przez powiat $\mathrm{i}$ inne podmioty.

7 Jedynie w ośmiu miastach aglomeracji śląskiej współczynnik ten jest mniejszy niż jeden. Ze względu na bliskość wielu dużych ośrodków konkurencja o ucznia odbywa się tam między miastami. 
(tabela 2). Natomiast w otoczeniu tych miast wartości współczynnika skolaryzacji są niskie i bardzo niskie.

Tabela 2. Podstawowe statystyki współczynnika skolaryzacji dla młodzieży pierwszych klas szkół ponadgimnazjalnych w powiatach ziemskich i grodzkich

\begin{tabular}{l|c|c|c|c} 
jednostka samorządu terytorialnego & średnia & mediana & minimum & maksimum \\
\hline powiat ziemski & 0,73 & 0,78 & 0,00 & 1,28 \\
\hline miasto na prawach powiatu & 1,66 & 1,58 & 0,53 & 3,39
\end{tabular}

Źródło: obliczenia własne na podstawie danych BDL GUS.

Zmiany demograficzne i decyzje edukacyjne młodzieży powodują, że to właśnie w szkołach zlokalizowanych w powiatach ziemskich ubyło w ostatnich latach najwięcej uczniów - por. tabela 3. Podczas gdy w miastach na prawach powiatu ubyło ok. 9\% uczniów w klasach pierwszych, w powiatach ziemskich w 2016 r. do klas pierwszych zgłosiło się przeciętnie mniej o 19\% uczniów niż w 2012 r.

Tabela 3. Zmiana liczby uczniów w pierwszych klasach szkół

ponadgimnazjalnych dla młodzieży w latach 2012-2016 (w \%)

\begin{tabular}{|c|c|c|c|c|c|}
\hline $\begin{array}{l}\text { jednostka samorządu } \\
\text { terytorialnego }\end{array}$ & populacja & średnia & mediana & minimum & maksimum \\
\hline \multirow{2}{*}{ powiat ziemski } & $\begin{array}{l}\text { uczniowie szkół } \\
\text { na terenie powiatu ogółem }\end{array}$ & -19 & -18 & -100 & 21 \\
\hline & $\begin{array}{l}\text { uczniowie szkół } \\
\text { prowadzonych przez powiat }\end{array}$ & -20 & -19 & -94 & 17 \\
\hline \multirow{2}{*}{$\begin{array}{l}\text { miasto } \\
\text { na prawach powiatu }\end{array}$} & $\begin{array}{l}\text { uczniowie szkół } \\
\text { na terenie powiatu ogółem }\end{array}$ & -9 & -9 & -32 & 14 \\
\hline & $\begin{array}{l}\text { uczniowie szkół } \\
\text { prowadzonych przez powiat }\end{array}$ & -12 & -12 & -30 & 13 \\
\hline
\end{tabular}


Powyższe zestawienia dotyczyły uczniów szkół ponadgimnazjalnych wszystkich typów dla młodzieży, prowadzonych przez różne podmioty. Szczegółowa analiza zmian w liczbie uczniów klas pierwszych szkół ponadgimnazjalnych różnych typów prowadzonych przez samorządy pokazuje, że najmniejszy ubytek uczniów klas pierwszych dotyczył techników (wykres 6). Przeciętnie w 2016 r. było tylko ok. 8\% mniej uczniów rozpoczynających te szkoły niż w 2012 r. Przy czym w powiatach grodzkich było to tylko $5 \%$, a w ziemskich $9 \%$. W powiatach ziemskich przeciętnie o prawie $1 / 4$ zmniejszyła się liczba młodzieży rozpoczynającej naukę w liceach ogólnokształcących i zasadniczych szkołach zawodowych. W powiatach grodzkich tak znaczny spadek dotyczył tylko szkół zawodowych (28\%), a licea w największych miastach straciły przeciętnie tylko $12 \%$ uczniów. Ogółem największy spadek liczby uczniów klas pierwszych zanotowały zasadnicze szkoły zawodowe (o $24 \%$ ). Jak pokazuje wykres 6, zmiany te znacznie różnią się w zależności od jednostki samorządu terytorialnego. W 25 powiatach ziemskich i pięciu miastach uczniów rozpoczynających naukę w szkołach zawodowych przybyło, ale w 25 powiatach ziemskich i jednym mieście ubytek uczniów szkół zawodowych był większy niż 50\%.

Wykres 6. Zmiana liczby uczniów w pierwszych klasach różnych typów szkół

ponadgimnazjalnych dla młodzieży prowadzonych przez powiat w latach 2012-2016

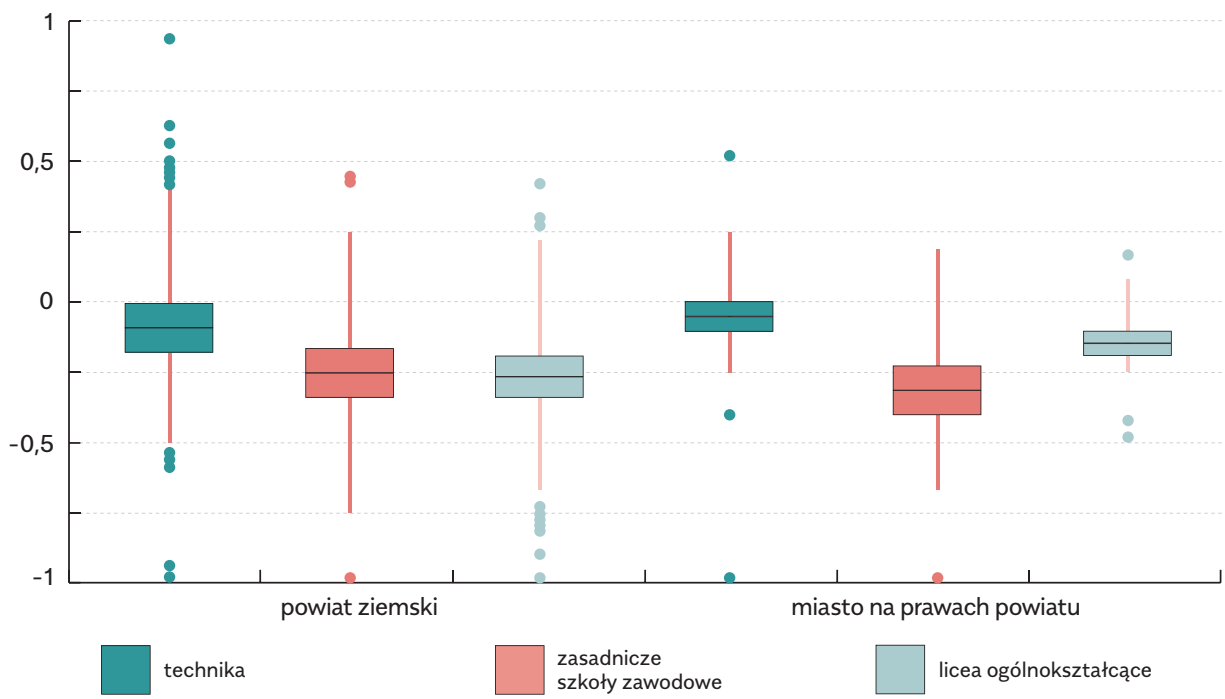

Źródło: obliczenia własne na podstawie danych BDL GUS. 
Największe miasta przyciągają coraz większą część młodzieży, szczególnie do liceów. Jednocześnie następuje przesunięcie uczniów decydujących się na kształcenie zawodowe z zasadniczych szkół zawodowych do techników. Ta pierwsza kwestia, powiązana ze zmianami demograficznymi, prowadzi do tego, że szkoły w powiatach ziemskich są małe, mniejsze niż w powiatach grodzkich. Tendencję tę potwierdzają dane przedstawione w poniższej tabeli.

Tabela 4. Liczba uczniów w szkołach ponadgimnazjalnych dla młodzieży prowadzonych przez powiaty w 2016 r.

\begin{tabular}{l|l|c|c|c|c}
\multirow{2}{*}{$\begin{array}{l}\text { jednostka samorządu } \\
\text { terytorialnego }\end{array}$} & typ szkoły & średnia & mediana & minimum & maksimum \\
\hline \multirow{2}{*}{ powiat ziemski } & technikum & 271,2 & 249,5 & 31 & 727 \\
\cline { 2 - 5 } & $\begin{array}{l}\text { zasadnicza } \\
\text { szkoła zawodowa }\end{array}$ & 148,5 & 129,7 & 0,813 & 545 \\
\cline { 2 - 5 } & $\begin{array}{l}\text { liceum } \\
\text { ogólnokształcące }\end{array}$ & 233,5 & 224,5 & 9 & 668 \\
\hline \multirow{2}{*}{$\begin{array}{l}\text { technikum } \\
\text { na prawach powiatu }\end{array}$} & $\begin{array}{l}\text { zasadnicza } \\
\text { szkoła zawodowa }\end{array}$ & 131,3 & 122,3 & 59,67 & 267 \\
\cline { 2 - 5 } & $\begin{array}{l}\text { liceum } \\
\text { ogólnokształcące }\end{array}$ & 357,5 & 353,2 & 81 & 619,2
\end{tabular}

W technikach i liceach ogólnokształcących prowadzonych przez powiaty ziemskie jest przeciętnie o ok. 100 uczniów mniej niż w szkołach tego samego typu prowadzonych przez miasta na prawach powiatu. Jedynie zasadnicze szkoły zawodowe są nieco większe w powiatach ziemskich niż grodzkich (o kilkanaście osób). Tabela pokazuje również, że ogółem zasadnicze szkoły zawodowe są najmniejszymi placówkami spośród szkół ponadgimnazjalnych dla młodzieży. Oczywiście należy pamiętać, że bardzo często samorządy prowadzą zespoły szkół, gdzie razem funkcjonują szkoły różnych typów, stąd w wartościach minimalnych pojawiają się tak niewielkie (nawet ułamkowe) wartości.

Należy również podkreślić, że takie przesunięcia uczniów prowadzą do tego, że do szkół kształcących zawodowo, a zwłaszcza zasadniczych szkół zawodowych, trafiają młodzi ludzie z najtrudniejszych środowisk 
i o największych problemach. Jak pokazuje poniższy cytat z rozmów prowadzonych w ramach badania BECKER, problem negatywnej selekcji dostrzegają dyrektorzy tych szkół:

„O4: [...] jest trudniej zrobić w ogóle rekrutację do tych szkół [kształcących zawodowo], że się cieszą niestety takim mniejszym zainteresowaniem jak licea ogólnokształcące [...]. Przynajmniej ja tak zauważyłam, że do liceów ogólnokształcących ja mam zawsze pełny nabór, nawet mam w kim wybierać, a jeżeli chodzi o technika, brakuje mi często, te klasy są otwierane dzięki starostwu [...].

O5: W związku z tym kandydaci są słabsi.

04: Słabsi, bo się bierze w tym momencie (wszystkich) uczniów".

[BECKER, wywiad grupowy $z$ dyrektorami szkół ponadgimnazjalnych]

Potwierdzają to również informacje o zdawalności matury. Zgodnie z sprawozdaniem Centralnej Komisji Egzaminacyjnej w 2016 r. egzamin maturalny zdało $85 \%$ przystępujących do niego absolwentów liceów ogólnokształcących i 68\% absolwentów techników (CKE 2017).

Decyzja młodzieży o wyborze typu i lokalizacji szkoły ponadgimnazjalnej wyraźnie wiąże się też z sytuacją finansową rodziców. W badaniu BECKER wykazano, że gdy uczeń decyduje się na wybór szkoły ponadgimnazjalnej, do której musi dojeżdżać, dla rodzica z powiatu ziemskiego oznacza to istotne wydatki (przeciętnie ok. 1200 zł rocznie), ponad dwukrotnie wyższe niż dla rodzin dzieci mieszkających w mieście. Prowadzi to często do sytuacji, gdy decyzja o kierunku kształcenia ponadgimnazjalnego nie jest podyktowana zainteresowaniami czy umiejętnościami ucznia, a dostępnością szkoły.

„B: No to jak to się stało, że w takim razie stolarz? Od mechanika do stolarza to chyba trochę jest rozstrzał, co?

01: To znaczy ten zawód, co stolarz, to ja już mu wybrałam, bo naprawdę już nie wiedzieliśmy gdzie co. Mówię, no to trudno, będzie taki, jak ja mu załatwię. [...] no, trudno, pasowało i autobusem dojechać i z powrotem. Soboty wolne, bo za mechanika musiałby i w sobotę jechać. Na przykład do Sępólna to on by nie miał w ogóle czym w sobotę dojechać".

[BECKER, wywiad rodzinny, powiat sępoleński] 
Należy pamiętać, że w przypadku młodzieży ważna jest nie tyle możliwość dojazdu do szkoły samochodem osobowym, co transportem publicznym. Szczegółowa analiza lokalizacji szkół ponadgimnazjalnych w Polsce pokazuje, że z terenu wielu (ok. 1/5) gmin w Polsce do żadnej szkoły ponadgimnazjalnej nie można dostać się w ciągu pół godziny jazdy transportem publicznym. Problem ten dotyczy przede wszystkim młodzieży mieszkającej na obszarach wiejskich i przygranicznych (Komornicki 2019).

\section{Koszty kształcenia zawodowego}

Jak zaznaczono powyżej, wielkość szkoły wpływa na wydatki z nią związane. W przeliczeniu na ucznia szkoły mniejsze wymagają zwykle większych nakładów. Tymczasem mimo że szkoły w powiatach ziemskich są mniejsze, wydatki na ucznia są w nich niższe niż w miastach na prawach powiatu (wykres 7). Poszukując wyjaśnienia tej odbiegającej od standardu zależności, przeanalizujmy dwie kolejne kwestie, które mogą wpływać na wysokość wydatków w przeliczeniu na ucznia - zróżnicowanie kosztów kształcenia w zależności od typu szkoły i profilu kształcenia oraz możliwości finansowe samorządów. Na kolejnym rysunku oprócz zróżnicowania wydatków na szkoły kształcące zawodowo pokazano również wydatki na licea ogólnokształcące. 
Wykres 7. Zróżnicowanie wydatków na ucznia różnych typów szkół ponadgimnazjalnych dla młodzieży (w tys. PLN)

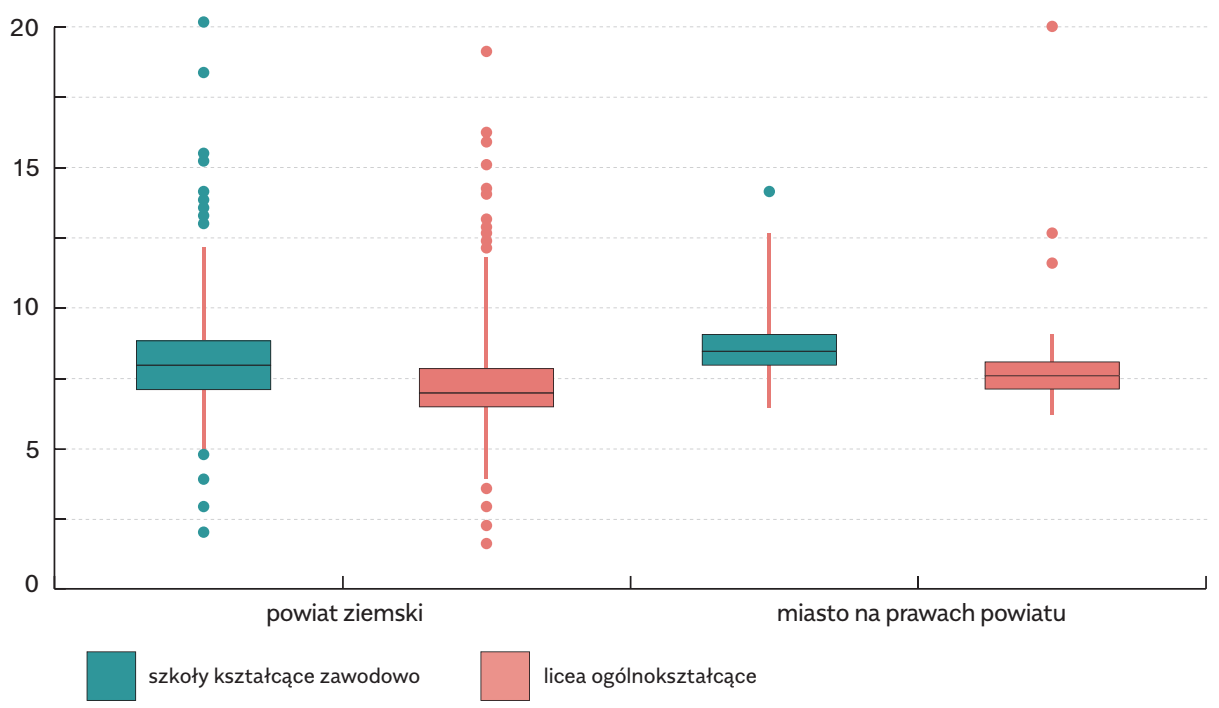

Źródło: opracowanie własne na podstawie danych z sprawozdań budżetowych RB28 i danych BDL GUS.

W przypadku zarówno liceów, jak i szkół kształcących zawodowo widać, że przeciętnie powiaty ziemskie wydają na ucznia mniej niż miasta. Jednocześnie - jak pokazuje wykres 7 - wydatek na ucznia w liceach jest w obu typach samorządów niższy niż w szkołach zawodowych (o ok. $15 \%)$. Szkoły kształcące zawodowo są droższe niż te, które oferują nauczanie tylko ogólne. W szkołach pierwszego typu częściej pracuje się w mniejszych grupach, a więc potrzeba większej liczby nauczycieli w przeliczeniu na ucznia. Dodatkowo tam, gdzie odbywa się więcej zajęć praktycznych, zużywa się więcej materiałów pomocniczych. Zależność tę potwierdzają dane o strukturze wydatków w szkołach. Poniższy wykres pokazuje strukturę bieżących wydatków samorządów powiatowych na prowadzone przez nie szkoły ponadgimnazjalne (wydatki bieżące po odjęciu wydatków na dotacje dla innych podmiotów). W obu przypadkach największą kategorię wydatków stanowią wydatki na wynagrodzenia wraz z pochodnymi ( $w$ tym z funduszem świadczeń socjalnych). Jednak w szkołach zawodowych wynagrodzenia stanowią nieco 
mniejszą część w strukturze wydatków (o ok. 2 pkt. proc.), a większe są wydatki na pomoce szkolne (o ok. 2 pkt. proc.). Należy pamiętać, że na wykresie przedstawiono informację o szkołach zawodowych kształcących w różnych zawodach. Tymczasem koszty w zależności od profilu kształcenia są bardzo różne. Najtańsze są profile związane z administracją i usługami (Stasiowski, Kłobuszewska, Drogosz-Zabłocka 2016).

Rysunek 8. Struktura wydatków na szkoły zawodowe i licea ogólnokształcące prowadzone przez powiaty $(\mathrm{w} \%)$

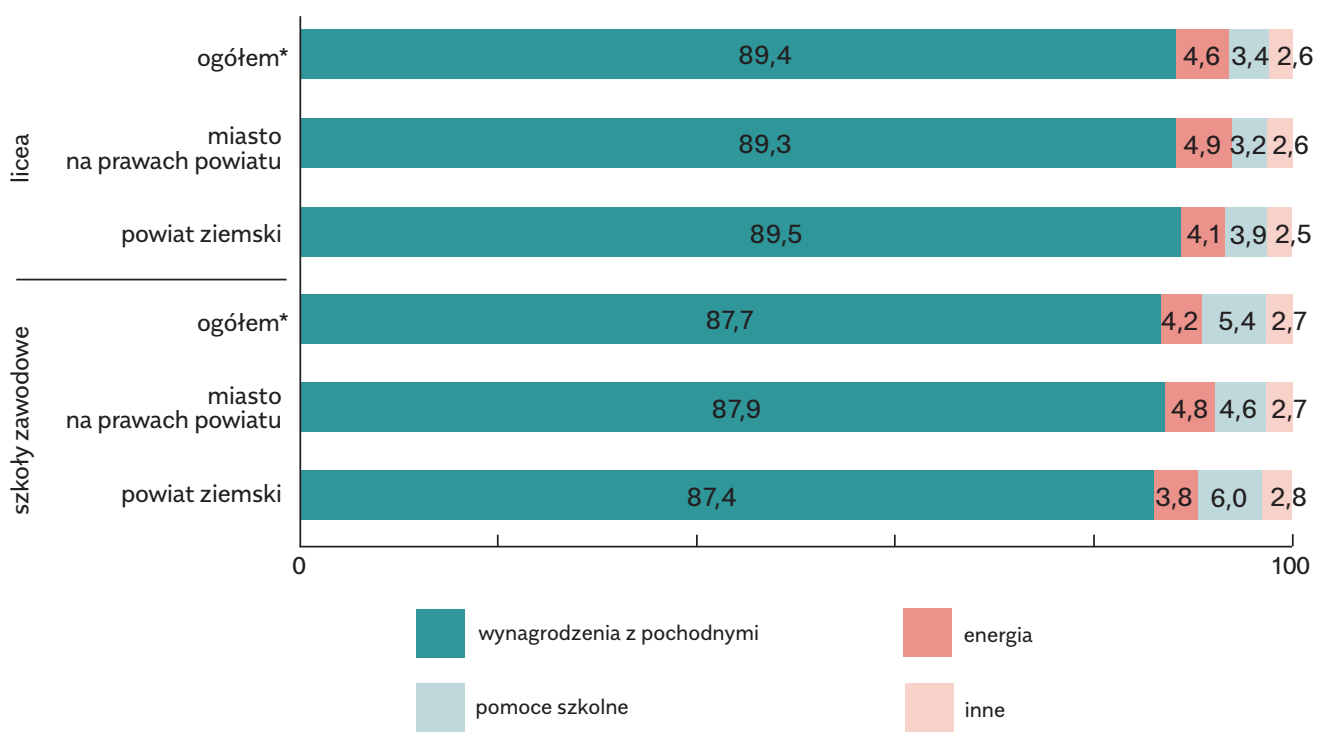

* Ogólne statystyki dla powiatów i miast na prawach powiatu.

Źródło: opracowanie własne na podstawie danych z sprawozdań budżetowych RB28.

Tymczasem zgodnie z danymi z 2014 r. to właśnie w tym najmniej kosztownym profilu kształciło się ogółem najwięcej uczniów szkół kształcących zawodowo. Przy czym profil ten przeważa głównie w miastach na prawach powiatu (tabela 5). Powinno to oznaczać, że przeciętnie kształcenie w tych miastach jest nieco mniej kosztowne niż w powiatach ziemskich, zatem wydatki przeciętnie są nieznacznie niższe. Tymczasem, jak już wskazywano, jest odwrotnie - mniej na ucznia szkoły kształcącej zawodowo wydają powiaty ziemskie. Koszty 
kształcenia nie są zatem najlepszym wyjaśnieniem różnic w wydatkach na szkoły w powiatach ziemskich i grodzkich.

Tabela 5. Profile kształcenia młodzieży w szkołach kształcących zawodowo

prowadzonych przez samorządy powiatowe w 2014 r. (w \%)

\begin{tabular}{|c|c|c|c|c|c|c|c|c|}
\hline $\begin{array}{l}\text { jednostka } \\
\text { samorządu } \\
\text { terytorialnego }\end{array}$ & $\begin{array}{l}\text { admini- } \\
\text { stracyjno- } \\
\text {-usługowy }\end{array}$ & $\begin{array}{l}\text { budow- } \\
\text { lany }\end{array}$ & $\begin{array}{c}\text { elek- } \\
\text { tryczny }\end{array}$ & $\begin{array}{l}\text { mecha- } \\
\text { niczny }\end{array}$ & $\begin{array}{l}\text { rolniczo- } \\
\text {-leśny }\end{array}$ & $\begin{array}{c}\text { arty- } \\
\text { styczny }\end{array}$ & $\begin{array}{c}\text { gastrono- } \\
\text { miczno- } \\
\text {-turystyczny }\end{array}$ & zdrowie \\
\hline powiat ziemski & 21 & 7 & 13 & 20 & 14 & 0 & 23 & 0 \\
\hline $\begin{array}{l}\text { miasto } \\
\text { na prawach } \\
\text { powiatu }\end{array}$ & 26 & 10 & 21 & 14 & 8 & 0 & 20 & 0 \\
\hline ogółem* & 23 & 8 & 16 & 18 & 12 & 0 & 22 & 0 \\
\hline
\end{tabular}

* Ogólne statystyki dla powiatów i miast na prawach powiatu.

Dane nie sumują się do $100 \%$ ze względu na zaokrąglenia.

Źródło: opracowanie własne na podstawie danych SIO.

\section{Możliwości finansowe samorządów powiatowych}

Jak odnotowano na początku tego rozdziału, celem reform systemu edukacji i struktury samorządu terytorialnego rozpoczętych pod koniec XX w. w Polsce było zmobilizowanie młodzieży w jej decyzjach edukacyjnych do wyboru głównie szkół kończących się maturą, zwłaszcza szkół ogólnokształcących. Fakt, że cel ten został osiągnięty, wiąże się nie tylko z niechęcią młodych ludzi do kształcenia zawodowego, ale również z jakością oferty w zakresie tego typu kształcenia kierowaną do nich przez samorządy. Jak się uważa, bardzo duży wpływ miał na to kształt systemu finansowania edukacji zawodowej. Zadania związane z organizacją i finansowaniem oświaty są zadaniem własnym samorządów. Oznacza to, że wydatki związane z tymi zadaniami pokrywane są z budżetu powiatów - ich dochodów własnych oraz subwencji. Dla realizacji zadań oświatowych największe znaczenie ma część oświatowa subwencji. Subwencja składa się z kwoty bazowej, kwoty uzupełniającej, kwoty na zadania pozaszkolne oraz kwoty rezerwowej. Poszczególne części subwencji oświatowej obliczane są na podstawie przeliczeniowej liczby uczniów i wychowanków korzystających z zakresu zadań pozaszkolnych. Ustalenie tych wielkości odbywa się na 
podstawie różnych przeliczników - wag. Dla szkolnictwa zawodowego w 2000 r. wprowadzono jedną wagę $(0,15)$, niezależną od tego, jaki jest profil kształcenia zawodowego. Waga ta podwyższa tzw. kwotę bazową wyliczaną dla ucznia szkoły ponadgimnazjalnej kształcącej zawodowo. Jak zauważyli Herbst i Levitas (2013, s. 15), taki jednolity i niewysoki przelicznik wystarczał "na pokrycie kosztów funkcjonowania tylko tych szkół, które nie potrzebowały zaplecza warsztatowego i specjalistycznego wyposażenia i w których większość lekcji mogła się odbywać w «zwykłych» klasach. W naturalny sposób system ten skłonił więc samorządy do zamykania tych placówek, które uczyły bardziej kosztownych (z perspektywy budżetu samorządowego) zawodów".

Subwencja dofinansowuje zadania oświatowe. Jej wysokość jest co roku ustalana w ustawie budżetowej. Zgodnie z art. 28 Ustawy z dnia 13 listopada $2013 \mathrm{r}$. o dochodach jednostek samorządu terytorialnego nie może być ona niższa niż w roku bazowym i powinna być skorygowana o zmiany z tytułu realizowanych przez samorządy zadań oświatowych. Coroczne wyliczenia kwoty tej subwencji są bardzo często krytykowane przez przedstawicieli samorządów. Uważają oni, że są one mało transparentne i subwencja jest zaniżana (Gniadkowski 2017, 2013). Jak zaznaczono, podział subwencji między samorządy dokonuje się na podstawie algorytmu, który również co roku jest modyfikowany i podawany w rozporządzeniu Ministerstwa Edukacji Narodowej. W odniesieniu do szkół kształcących zawodowo warto odnotować wzrost wagi przeliczeniowej dla uczniów szkół ponadgimnazjalnych prowadzących kształcenie zawodowe. W latach 2000-2008 wynosiła ona 0,15, następnie została podniesiona do 0,17 (w 2009 r.), w latach 2010-2015 było to 0,19 , w 2016 r. - 0,23. W 2013 r. uwzględniono również specjalną wagę dla uczestników kwalifikacyjnych kursów zawodowych organizowanych przez szkoły i placówki prowadzone przez jednostki samorządu terytorialnego.

Subwencja jest dochodem, którego rozdysponowanie powinno być zgodne z decyzją własną samorządu. Jednak od 2015 r. wprowadzono w polskich przepisach zasadę, że jednostki samorządu terytorialnego zobowiązane są, aby w danym roku budżetowym na realizację zadań wymagających specjalnej organizacji nauki i metod pracy dla dzieci i młodzieży ze specjalnymi potrzebami edukacyjnymi przeznaczały środki w wysokości nie niższej, niż zostało wyliczone w subwencji 
oświatowej na realizację tych zadań8. Z jednej strony rozwiązanie to wynikało z troski o właściwe finansowanie dzieci i młodzieży w najtrudniejszej sytuacji, z drugiej oznacza zaś, że ta część subwencji stała się dla samorządów de facto dotacją. Spowodowało to trudności szczególnie w samorządzie powiatowym, gdyż to on jest odpowiedzialny za szkolnictwo specjalne. Jak pokazuje poniższa tabela, udział wydatków na szkolnictwo specjalne rósł w poprzednich latach w odniesieniu zarówno do wydatków ogółem, jak i do wydatków na oświatę. Przypomnijmy raz jeszcze, że w tym samym okresie udział wydatków na szkoły kształcące zawodowo spadł. Można przypuszczać, że mamy do czynienia z sytuacją, gdy obowiązkowe wydatki wypychają te, wobec których samorządy mają większą swobodę.

Tabela 6. Udział wydatków bieżących na szkoły specjalne w wydatkach bieżących powiatów ogółem i w wydatkach bieżących na oświatę w latach 2008-2012 (w \%)

\begin{tabular}{l|c|c}
\multirow{2}{*}{} & \multicolumn{2}{|c}{$\begin{array}{c}\text { w wydatkach samorządów ogółem } \\
\text { powiaty ziemskie }\end{array}$} \\
\cline { 2 - 3 } 2008 & 4,8 & w wydatkach na oświatę (działy 801 i 854) \\
\hline 2012 & 5,6 & 11,1 \\
\hline 2016 & 6,1 & \multicolumn{2}{|c}{12,8} \\
\hline 2008 & \multicolumn{3}{|c}{ miasta na prawach powiatu } \\
\hline 2012 & 1,9 & \multicolumn{2}{|c}{5,0} \\
\hline 2016 & 2,0 & 5,3 \\
\hline
\end{tabular}

Źródło: opracowanie własne na podstawie sprawozdań budżetowych RB 28.

Samorządy mogą zwiększać środki przeznaczane na oświatę z dochodów własnych. Jednak dochody powiatów ziemskich są bardzo ograniczone, bowiem nie dysponują one żadnymi znacznymi dochodami własnymi poza udziałem w podatkach dochodowych (PIT i CIT). W przeciwieństwie do gmin, w tym miast na prawach powiatu, mają o szczególnych rozwiązaniach służących realizacji ustawy budżetowej na rok 2016, art. 13. 
bardzo ograniczone możliwości samodzielnego kształtowania swoich dochodów. Podczas gdy, jak pokazuje poniższy wykres, w 2016 r. dochody własne miast na prawach powiatu stanowiły ponad $60 \%$ dochodów tych jednostek, w powiatach ziemskich było to o połowę mniej.

Wykres 9. Struktura dochodów powiatów ziemskich i grodzkich w 2016 r.

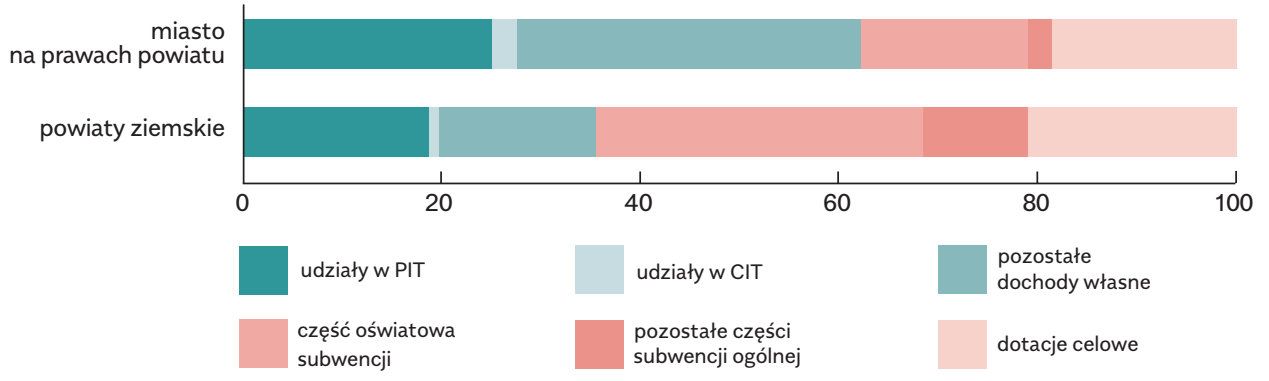

Źródło: opracowanie własne na podstawie danych BDL GUS.

Sytuacja finansowa powiatów ziemskich jest od wielu lat przedmiotem dyskusji. Jednak nadal nie dokonano zmian w dochodach tych jednostek samorządu terytorialnego. Problem braku elastyczności budżetów powiatów ziemskich dobrze obrazuje poniższa wypowiedź:

"[...] powiaty nie mają z kolei dochodów takich własnych, nie mają żadnych podatków, nie mają żadnej ziemi, nasz powiat nie ma nic do sprzedania, tak jak gminy sprzedają jakieś majątki, bo one powstały w roku dziewięćdziesiątym, powiaty powstały w dziewięćdziesiątym ósmym. Tak naprawdę zaczęły działać od pierwszego stycznia dziewięćdziesiątego dziewiątego roku, już nie było czego tym powiatom dać, jakich zasobów. Dano nam tylko szkoły, zarządzanie drogami, i tak naprawdę majątek tylko pod tymi szkołami, tyle ziemi, co tam szkoła stoi, natomiast dodatkowych żadnych majątków powiat nie posiada, nie ma czego sprzedać, nie ma dodatkowych środków, żeby dofinansować te szkoły". [BECKER, wywiad ze skarbnikiem powiatu ziemskiego] 
Sytuacja ta powoduje, że podstawowym źródłem finansowania przez powiaty ziemskie zadań z zakresu oświaty jest część oświatowa subwencji. W 2016 r. powiaty ziemskie przeciętnie w 93\% sfinansowały wydatki na oświatę z otrzymanej subwencji. W przypadku miast na prawach powiatu było to tylko $75 \%$. Co więcej, było 40 powiatów ziemskich, których wydatki na oświatę nie przekroczyły kwoty otrzymanej z subwencji. W żadnym największym mieście nie doszło do takiej sytuacji.

Wykres 10. Udział subwencji w finansowaniu wydatków bieżących samorządów na oświatę (z działów 801 i 854) bez wydatków na przedszkola

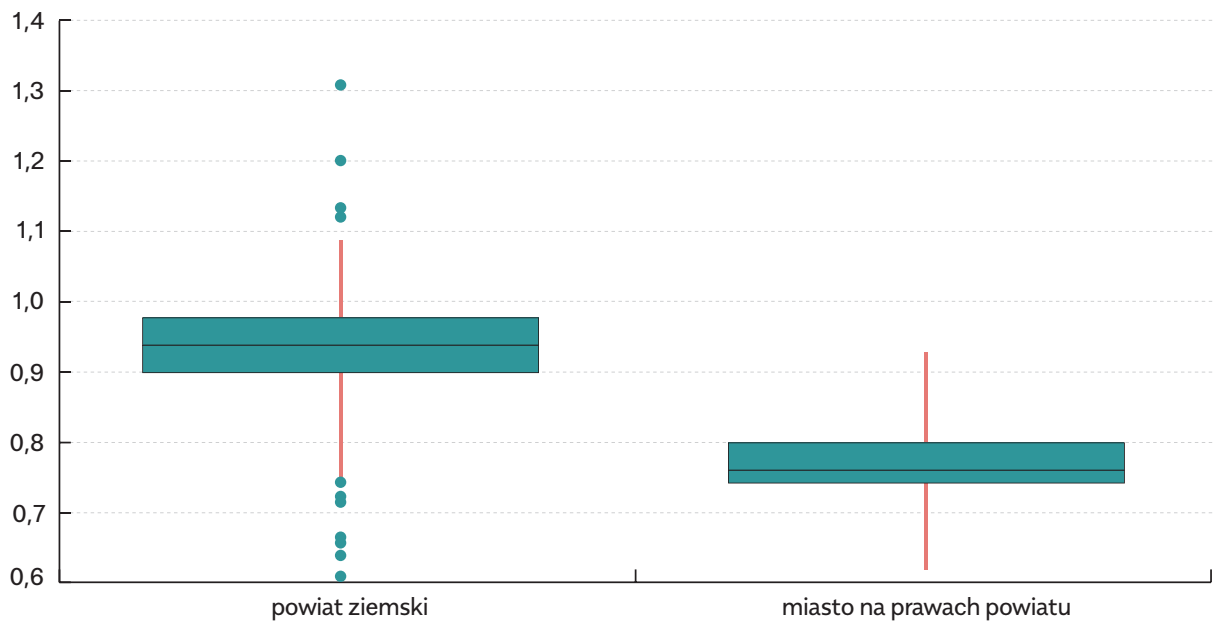

Źródło: opracowanie własne na podstawie sprawozdań budżetowych RB 28 i RB27.

Oczywiście przy dokonywaniu takiego zestawienia należy pamiętać o różnicach w zadaniach oświatowych obu typów powiatów. Niemniej ta dysproporcja w zakresie dofinansowania zadań oświatowych wyraźnie wiąże się z różnicami w budżecie powiatów ziemskich i grodzkich. Brak możliwości dofinansowania zadań oświatowych znajduje wyjaśnienie w tym, że samorządy powiatowe wydają na ucznia swoich szkół mniej niż miasta na prawach powiatu. Dzieje się tak, mimo że szkoły w powiatach ziemskich są mniejsze. 
Samorządy, w tym powiaty ziemskie, przeprowadziły wiele inwestycji związanych ze szkołami zawodowymi. W ciągu ostatnich 10 lat (2007-2016) w ciągu roku wydawały średnio ponad 230 milionów zł na szkoły zawodowe. Wydatki powiatów ziemskich stanowiły ok. $63 \%$ tej sumy. Należy nadmienić, że ok. 30\% wydatków inwestycyjnych powiatów ziemskich wiązało się z projektami dofinansowanymi z UE (w miastach na prawach powiatu było to $20 \%$ ). Jednak w zestawieniu z rocznymi wydatkami bieżącymi na szkoły kształcące zawodowo nie jest to imponująca kwota, gdyż jest to niewiele ponad $4 \%$ tych wydatków. Również, jeśli zestawimy to $z$ wydatkami lub dochodami ogółem samorządów, okaże się, że powiaty przeznaczają na inwestycje w szkoły kształcące zawodowo zaledwie niewielką część swojego budżetu. Średnio wydatki te stanowiły ok. 0,4\% budżetu powiatów ziemskich i 0,1\% budżetu powiatów grodzkich. Jeśli zestawimy to z danymi, że w analizowanym okresie inwestycje samorządów stanowiły ok. $12-15 \%$ budżetu w przypadku powiatów ziemskich i nawet ponad $20 \%$ w przypadku powiatów grodzkich, widać, że szkoły te nie są ich priorytetem inwestycyjnym.

Tabela 7. Wydatki inwestycyjne na szkoły kształcące zawodowo

(średnioroczna kwota z ostatnich 10 lat) w odniesieniu do wydatków

powiatów ogółem i bieżących na szkoły zawodowe w 2016 r. (w \%)

\begin{tabular}{l|c|c|c|c}
$\begin{array}{l}\text { jednostka samorządu } \\
\text { terytorialnego }\end{array}$ & średnia & mediana & minimum & maksimum \\
\hline & \multicolumn{3}{|c}{ w odniesieniu do wydatków ogółem } \\
\hline powiat ziemski & 0,6 & 0,4 & 0,0 & 4,8 \\
\hline $\begin{array}{l}\text { miasto } \\
\text { na prawach powiatu }\end{array}$ & 0,1 & 0,1 & 0,0 & 0,6 \\
\hline & w odniesieniu do wydatków bieżących na szkoły zawodowe \\
\hline powiat ziemski & 5,1 & 3,3 & 0,0 & 35,2 \\
\hline $\begin{array}{l}\text { miasto } \\
\text { na prawach powiatu }\end{array}$ & 3,1 & 2,2 & 0,0 & 15,7
\end{tabular}




\section{Podsumowanie}

Powyższa analiza pokazuje wyraźnie, że podstawowym problemem w organizacji i finansowaniu szkolnictwa zawodowego przez powiaty ziemskie jest ich sytuacja budżetowa. Chodzi tu zarówno o brak elastycznych dochodów własnych, jak i o obciążenie ich budżetu istotnymi wydatkami sztywnymi. Co więcej, w ostatnich latach następuje coraz większe usztywnienie wydatków, czego przykładem jest dodefiniowanie obowiązkowych wydatków na szkoły specjalne. Niestety nie idą za tym dodatkowe dochody. Samorządy miast na prawach powiatu mogą w większym niż powiaty ziemskie zakresie odpowiadać na te zmiany ze względu na możliwość korzystania z dochodów własnych. Ostatecznie powiaty ziemskie nie są w stanie przeznaczyć na szkoły dostatecznych środków, porównywalnych z tymi, jakie wydają miasta na prawach powiatu. Jeśli decentralizacja systemu organizacji oświaty ma być utrzymana, dla zwiększenia nakładów na edukację zawodową nie wystarczy tylko zwiększenie subwencji oświatowej, potrzebne jest wzmocnienie dochodów własnych powiatów. Jednocześnie należy postawić pytanie, czy istotnie w każdym powiecie potrzebne są szkoły ponadgimnazjalne, a szczególnie szkoły kształcące zawodowo. Zmiany demograficzne, a również migracja młodzieży powodują, że szkoły te są zwyczajnie za małe, aby efektywnie dostarczać usługę edukacyjną. Być może część powiatów, zamiast prowadzić takie placówki, powinna wspomagać transport młodzieży do szkół poza swój teren albo dopłacać do burs czy internatów, o ile zachodziłaby taka potrzeba. Zrównałoby to szanse na uzyskanie dobrego wykształcenia przez młodych ludzi z uboższych rodzin i z peryferyjnych powiatów, których rodzice nie zawsze mogą sobie pozwolić na sfinansowanie edukacji w większej odległości od domu. Rozwiązaniem problemów organizacji i finansowania sieci szkół zawodowych (i, szerzej, szkół dla młodzieży) poza dużymi miastami mogłoby być również przekazanie tego obowiązku do kompetencji samorządu wojewódzkiego. Przy czym samorząd ten, podobnie jak powiaty ziemskie, nie dysponuje elastycznymi dochodami własnymi, zatem konieczne byłoby zdefiniowanie na nowo dochodów tych podmiotów. 